\title{
Electric Arc Furnace Granulated Slag for Sustainable Concrete
}

Luigi Coppola ${ }^{a}$, Alessandra Buoso ${ }^{a}$, Denny Coffetti ${ }^{a}$, Patricia Kara ${ }^{b^{*}}$ and Sergio Lorenzi ${ }^{\mathrm{a}}$

aDISA, Department of Engineering and Applied Sciences, University of Bergamo, Italy

bIMS, Riga Technical University, Latvia

*corresponding author: patricia.e.kara@gmail.com

\section{Abstract}

This paper deals with the use of industrial by-products from Electric Arc Furnace (EAF) granulated slag for the partial replacement of natural aggregates commonly used to manufacture concrete. Three different gradings of EAF granulated slag were considered. The rheological and mechanical properties of concrete manufactured with a partial replacement of natural aggregates with slag were determined. Dry shrinkage of hardened concrete was evaluated. Results indicated that the maximum percentage of natural aggregate that can be replaced with EAF granulated slag is about $15 \%$ in order to limit the superplasticizer dosage required to attain the same workability class of the reference concrete mix at the end of the mixing procedure. The higher the percentage of granulated slag was, the higher the density, the elastic modulus in compression and the compressive strength of the concrete were. Dry shrinkage of the concrete increased by adding a greater amount of EAF granulated slag.

\section{Keywords}

Industrial by-products, electric arc furnace granulated slag, eco-sustainability, concrete

\section{Introduction}

Sustainable development issues have become very important after the Kyoto protocol was adopted in 1997 and especially in the last decade after the protocol entered into force in 2005. 
It was stressed out once again about the need to reduce wastes and preserve natural resources during The United Nations Framework Convention on Climate Change which was held in December 2015 in Paris. The production of concrete is characterized by a considerable demand of energy and raw materials, results in significant emissions of greenhouse gases, and has a big impact on the environment. Research on the sustainable progress in the field of construction industry, which involves $6 \%$ of world energy resources and $\mathrm{CO}_{2}$ emissions, has been intensively carried out in recent years [1-3]. Nowadays, natural aggregates and cement are two components in concrete production which are problematic from the point of view of sustainability [4]. The consumption of natural aggregates, which leads to inexorable hydrogeological modification of land, should obviously be reduced, for example, by considering the replacement of natural aggregates with industrial by-products in concrete production [5-7]. Durability and mechanical properties of structures manufactured by using industrial wastes are both important; the chemical and physical properties of the by-products must be seriously considered in concrete production [8-11].

Granulated blast furnace slag (GBS) is the most important steel industry by-product. The production is almost 0.23 tons of slag for each ton of cast iron and $0.1 \div 0.2$ tons for each ton of steel [12]. According to EUROSLAG data [13], the production of granulated blast furnace slag was 23 million tons in 2012. The huge amount of EAF granulated slag increases the waste disposal costs, and therefore, the need for recycling of by-products for economic and environmental reasons is leading to the development of slag utilization. The use of slag aggregates from iron and steel production in construction dates back to the Romans who used crushed slag from the crude iron production of that time to build their roads. Slag is particularly useful as an aggregate, due to the high mechanical resistance of the slag grains which exceeds those of many natural aggregates. The aggregate standards contain additional requirements for blast furnace slag and steel slag with respect to volume stability. In recent years about $60 \%$ of blast furnace slag has been used for cement production/concrete addition and about $24 \%$ for road construction. And from studies of the research carried out, the use of 
steel slag in blended cement and in road construction has been proposed by several researchers [14-22], but only a few brought feedback on steel slag's application as an aggregate in the concrete industry [23-25].

Furnace slag is generally treated and stabilized to replace natural aggregates in concrete manufacturing. Different aggregate grading $(10 \div 20,8 \div 12,4 \div 8,0 \div 4 \mathrm{~mm})$ is produced by crushing solid slag blocks and sieving [14]. Natural aggregate replacement is obviously economical for both the concrete producer for whom it reduces raw material utilization and for the steel industry in terms of the reduction of waste disposal.

The electric arc furnace slag generally used as a substitute for natural aggregate in concrete is sharp-cornered with a honeycombed surface texture. This characteristic can be useful to develop very strong interlocking properties [26]. Anastasiou and Papayianni [27] evaluated different properties of EAF granulated slag and concluded that the main properties of this industrial waste aggregates are over the limits of the standard natural aggregates.

The principal detrimental factor against using large amounts of steel slag as aggregates in concrete is the high content of free lime (free-CaO) and periclase $(\mathrm{MgO})$. Due to the content of these expansive oxides (free- $\mathrm{CaO}$ and $\mathrm{MgO}$ ), the EAF granulated slag is generally treated before its use in concrete. Ageing or weathering of slag, steam and autoclave curing of slag are generally performed to reduce expansive oxide contents [27-31].

\section{Materials and methods}

\subsection{Materials}

Several concrete mixes were produced by using EAF granulated slag as a partial replacement for natural aggregates. Fresh and hardened properties were evaluated and compared with those of a reference mix manufactured with natural aggregates only. A cement CE II/A-LL 42.5R (Italcementi Limestone Portland Cement) according to EN 197-1 was used. Dosage of a polycarboxylate-based superplasticizer was adjusted to attain the same workability at the end of the mixing (S4 class, according to EN 206-1) as that of the reference concrete mixes 
[32]. A chemical admixture (ester of acrylic or methacrylic acid monomer) having $1000 \mathrm{~g} / \mathrm{mol}$ side chain length and an acid/ester ratio equal to 3.5 was used. Three natural aggregates and three different EAF granulated slags were considered to manufacture experimental concrete mixes:

S1: fine sand $(0 \div 4 \mathrm{~mm})$

G1: fine gravel $(6 \div 14 \mathrm{~mm})$

G2: coarse gravel $(11 \div 22 \mathrm{~mm})$

L1: waste fine sand $(0 \div 4 \mathrm{~mm})$

L2: waste fine gravel $(8 \div 12 \mathrm{~mm})$

L3: waste gravel $(10 \div 20 \mathrm{~mm})$

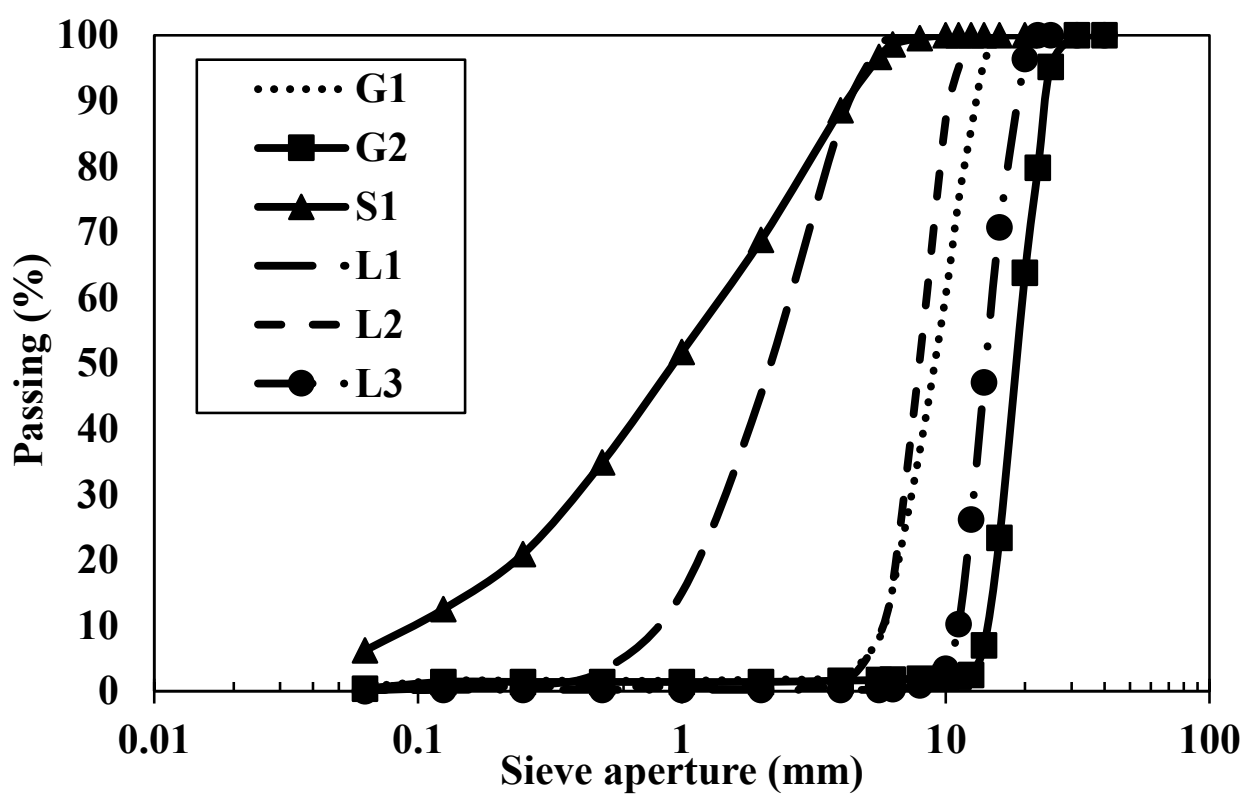

Figure 1. Grading curves of natural and waste aggregate

Natural and waste aggregate grading was evaluated by sieve analysis according to UNI EN 933-1 (Figure 1). It can be seen that waste aggregate grading curves are very similar to natural aggregate ones. In particular, EAF granulated slags L2 and L3 can be considered equivalent, in terms of grading, to natural gravels $\mathrm{G} 1$ and $\mathrm{G} 2$, respectively. Natural sand $\mathrm{S} 1$ is very similar, in terms of size, to waste fine sand L1, however $\mathrm{S} 1$ is finer than L1 (Figure 1).

Table 1. Chemical composition of the waste aggregates 


\begin{tabular}{|c|c|c|c|}
\hline \multicolumn{2}{|c|}{$\begin{array}{c}\text { Principal constituents } \\
\text { [weight \%] }\end{array}$} & \multicolumn{2}{c|}{$\begin{array}{c}\text { Element traces } \\
{[\mathrm{mg} / \mathrm{kg}]}\end{array}$} \\
\hline $\mathrm{CaO}$ & $25-30$ & $\mathrm{As}$ & $<15$ \\
\hline $\mathrm{CaO}_{\text {free }}$ & $0-4$ & $\mathrm{Cd}$ & $<30$ \\
\hline & & & $5000-$ \\
$\mathrm{SiO}_{2}$ & $8-18$ & $\mathrm{Cr}$ tot & 22000 \\
\hline $\mathrm{Al}_{2} \mathrm{O}_{3}$ & $3-10$ & $\mathrm{Cu}$ & $<300$ \\
\hline $\mathrm{MgO}$ & $2-9$ & $\mathrm{Hg}$ & $<0.5$ \\
\hline $\mathrm{Fe}_{\text {total }}$ & $20-30$ & $\mathrm{Ni}$ & $<70$ \\
\hline $\mathrm{Mn}_{\text {total }}$ & $2-8$ & $\mathrm{~Pb}$ & $<90$ \\
\hline $\mathrm{CaO} / \mathrm{SiO}_{2}$ & $1.7-4.0$ & $\mathrm{Zn}$ & $<900$ \\
\hline
\end{tabular}

Table 2. Density and water absorption of natural and waste aggregates

\begin{tabular}{|c|c|c|}
\hline Aggregates & $\begin{array}{c}\text { Density } \\
{\left[\mathrm{kg} / \mathrm{m}^{3}\right]}\end{array}$ & $\begin{array}{c}\text { Water absorption } \\
{[\%]}\end{array}$ \\
\hline G1 & 2670 & 1.04 \\
\hline G2 & 2650 & 1.71 \\
\hline S1 & 2670 & 0.70 \\
\hline L1 & 3337 & 4.32 \\
\hline L2 & 3320 & 2.89 \\
\hline L3 & 3328 & 2.46 \\
\hline
\end{tabular}

The chemical composition of the waste aggregates is summarized in Table 1. Water absorption and density of natural aggregates and slag waste were evaluated according to UNI EN 1097-6 (Table 2). EAF granulated slag showed higher density than natural aggregates as a consequence of their high iron content $(20 \div 30 \%$ vs weight). Hence, the higher the amount of slag was in the mix, the higher the density of concrete. Wastes showed higher water absorption compared to natural aggregates. Chemical analysis was also carried out according to UNI EN 1744-1: sulfate, sulfur and soluble chloride content were lower than the limits fixed by EN 12620. Petrographic analysis (UNI EN 932-3) evidenced no gypsum, amorphous silica or pyrite in waste aggregates. Blue-methylene test (UNI EN 933-9) excluded presence of mud and clay in EAF granulated slag. Los Angeles test was performed on both waste and natural aggregates according to UNI EN 1097-2: the mass loss of material having passed the $1.6 \mathrm{~mm}$ 
control sieve was 17\% (LA20 according to UNI EN 1097-2) and 26\% (LA30 according to UNI EN 1097-2), respectively.

\subsection{Tests on concrete}

In order to evaluate the possibility to replace natural aggregates with EAF granulated slag concrete mixes were manufactured. Both natural and waste aggregates were mixed to meet the Bolomey curve. The total aggregate volume (natural and waste) was fixed at volume of $0.708 \mathrm{~m}^{3}$ for all concrete mixes. Concrete mixes were manufactured by increasing EAF aggregates to replace up to $25 \%$ of the natural aggregates by mass. Dry waste aggregates were considered and the water was adjusted in order to compensate the absorption by aggregates during the mixing procedure. The w/c ratio was fixed to 0.54 and the superplasticizer dosage was adjusted to attain the same workability (S4 class according to EN 206-1) of the reference mix without waste aggregates. Concrete flow was measured at the end of the mixing and after 30 and 60 minutes according to UNI EN 12350-2. Entrapped air and density were also evaluated on fresh concrete according to UNI EN 12350-6 and UNI EN 12350-7, respectively. Density and compressive strength at age of $1,2,3,7$ and 28 days, flexural strength, splitting tensile strength and elastic modulus at the age of 28 days and dry shrinkage up to 90 days were determined for hardened concrete.

\section{Results and discussions}

\subsection{Fresh concrete}

Compositions and fresh properties of concrete mixes are summarized in Table 3. The higher the waste aggregate addition was, the lower the initial workability: the higher amount of EAF granulated slag showed an increase of the superplasticizer dosage (Table 3). This effect can be ascribed to the crushed nature and rough texture of waste aggregates that increase water demand to attain the same initial workability of the reference mix. Workability loss at 60 minutes became more pronounced by increasing waste aggregates addition. This effect can be explained by considering the higher water absorption of EAF granulated slag (Table 2) that 
partially consumes the mixing water during concrete transportation. This fact could be solved by soaking the waste aggregates before the mixing procedure in order to avoid the water absorption and, consequently, the slump loss.

Table 3. Composition and properties of fresh concrete

\begin{tabular}{|c|c|c|c|c|c|}
\hline COMPOSITION & REF. & MIX_10 & MIX_15 & MIX_20 & MIX_25 \\
\hline CE II/A-LL 42.5R [kg/m³] & 320 & 320 & 320 & 320 & 320 \\
\hline Water $\left[\mathrm{kg} / \mathrm{m}^{3}\right]$ & 174 & 174 & 174 & 174 & 174 \\
\hline$w / c$ ratio & 0.54 & 0.54 & 0.54 & 0.54 & 0.54 \\
\hline $\begin{array}{l}\text { Superplasticizer dosage } \\
\text { [\% vs cement mass] }\end{array}$ & 0.95 & 0.95 & 1.10 & 1.15 & 1.20 \\
\hline $\mathrm{S} 1\left[\mathrm{~kg} / \mathrm{m}^{3}\right]$ & 993 & 946 & 946 & 946 & 983 \\
\hline $\mathrm{G} 1\left[\mathrm{~kg} / \mathrm{m}^{3}\right]$ & 441 & 369 & 331 & 303 & 208 \\
\hline $\mathrm{G} 2\left[\mathrm{~kg} / \mathrm{m}^{3}\right]$ & 460 & 389 & 332 & 313 & 228 \\
\hline $\begin{array}{l}\text { Total natural aggregate } \\
{\left[\mathrm{kg} / \mathrm{m}^{3}\right]}\end{array}$ & 1894 & 1704 & 1609 & 1562 & 1419 \\
\hline $\mathrm{L} 1\left[\mathrm{~kg} / \mathrm{m}^{3}\right]$ & 0 & 165 & 224 & 140 & 120 \\
\hline $\mathrm{L} 2\left[\mathrm{~kg} / \mathrm{m}^{3}\right]$ & 0 & 35 & 82 & 140 & 235 \\
\hline L3 $\left[\mathrm{kg} / \mathrm{m}^{3}\right]$ & 0 & 35 & 44 & 130 & 235 \\
\hline $\begin{array}{l}\text { Total waste aggregate } \\
{\left[\mathrm{Kg} / \mathrm{m}^{3}\right]}\end{array}$ & 0 & 235 & 350 & 410 & 590 \\
\hline $\begin{array}{l}\text { EAF slag substitution } \\
\text { [\% mass of natural } \\
\text { aggregates] }\end{array}$ & 0 & 10 & 15 & 20 & 25 \\
\hline Initial workability class & S4* & $\mathrm{S} 4^{*}$ & $\mathrm{~S} 4^{*}$ & $\mathrm{~S} 4^{*}$ & S4* \\
\hline $\begin{array}{l}\text { Slump [mm] at } 0^{\prime}-30^{\prime} \\
60^{\prime}\end{array}$ & $\begin{array}{c}200-190- \\
185\end{array}$ & $\begin{array}{c}200-180 \\
160\end{array}$ & $\begin{array}{l}200-170 \\
155\end{array}$ & $\begin{array}{c}170-150 \\
120\end{array}$ & $\begin{array}{c}170-140 \\
105\end{array}$ \\
\hline Density $\left[\mathrm{kg} / \mathrm{m}^{3}\right]$ & 2390 & 2435 & 2460 & 2470 & 2500 \\
\hline Entrapped air [\%] & 1.0 & 1.4 & 2.4 & 2.0 & 1.9 \\
\hline
\end{tabular}

${ }^{*}$ Class S4, 160-210mm slump according to EN 206-1

The maximum percentage of EAF granulated slag in concrete production is $25 \%$ to limit the increase of water demand and workability loss. Experimental data indicate that the optimal waste addition is $15 \%$ with respect to the mass of natural aggregates. In fact, this percentage requires a moderate increase of the superplasticizer dosage and, at the same time, it does not promote a significant workability loss at 60 minutes. Since the density of EAF granulated slag is higher than natural aggregates the higher the waste replacement, the higher the density of fresh concrete (Table 2 and Table 3). The air entrapping tendency of the mixes increases with the EAF granulated slag content as a consequence of the side effect ascribable to the 
higher dosage of the superplasticizer required to attain the same initial workability of the reference mix (consistency class S4). In fact, the air content approached about $2 \%$ for the concrete manufactured by considering a slag replacement greater than or equal to $15 \%$.

\subsection{Hardened concrete}

Compressive strength tests were carried out to evaluate the effect of waste aggregate addition on the mechanical properties of concrete. The cubic specimens were soaked in water at a temperature of $+20^{\circ} \mathrm{C}$ for $1,2,3,7$ and 28 days. An increase in waste aggregates addition generally improves the compressive strength of concrete at early ages (Figure 2).

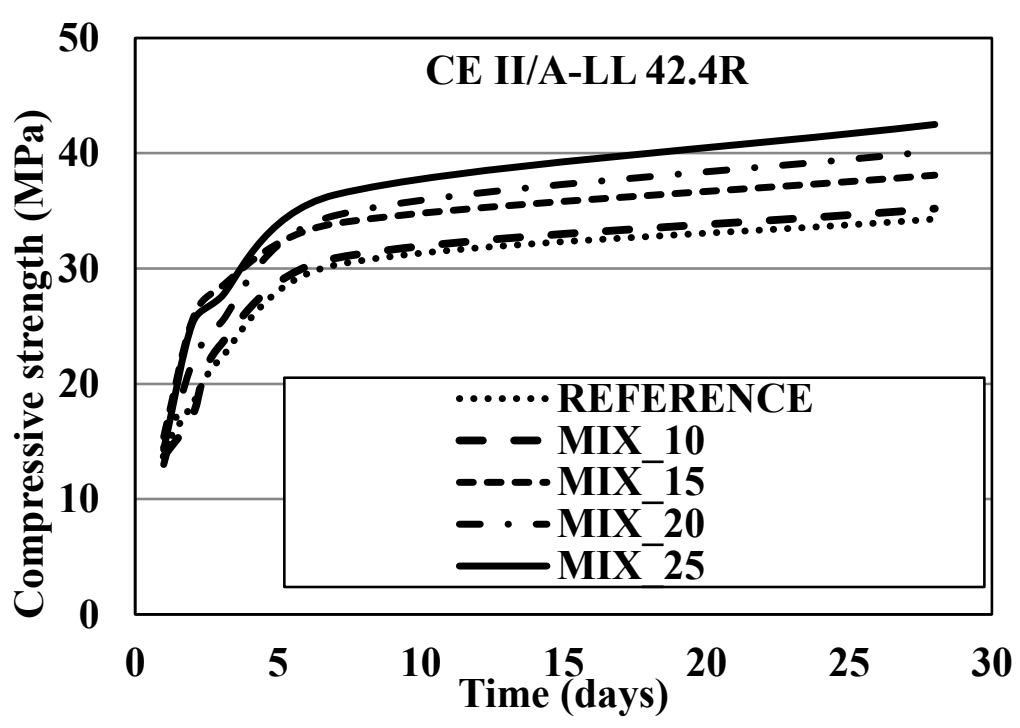

Figure 2. Compressive strength of concrete mixes

The higher compressive strength of concretes manufactured with EAF granulated slag is mostly related to the higher Los Angeles class of wastes with respect to that of natural aggregates. Furthermore, the rough texture of slag aggregates is responsible for the improvement of the quality of the transition zone at the interface of the aggregate and cement matrix, and, consequently, for the higher compressive strength of concrete containing EAF granulated slag. Only 1-day compressive strength of concretes manufactured with EAF granulated slag was lower compared to that of the reference mix. This effect can be ascribed to the side effect of retardation of the superplasticizer: the higher the dosage, the lower the compressive strength at the age of 1 day due to the lower cement hydration rate. Results of 
the four points bending tests carried out according to UNI 12390-5 and splitting tensile test (UNI 6135) are shown in Figure 3. Replacement of natural aggregates with EAF granulated slag slightly improves both the flexural and splitting tensile strength of concrete. This effect can be ascribed to the rough texture of waste aggregates and, consequently, to the improvement of the transition zone at the interface of the aggregate and cement matrix.

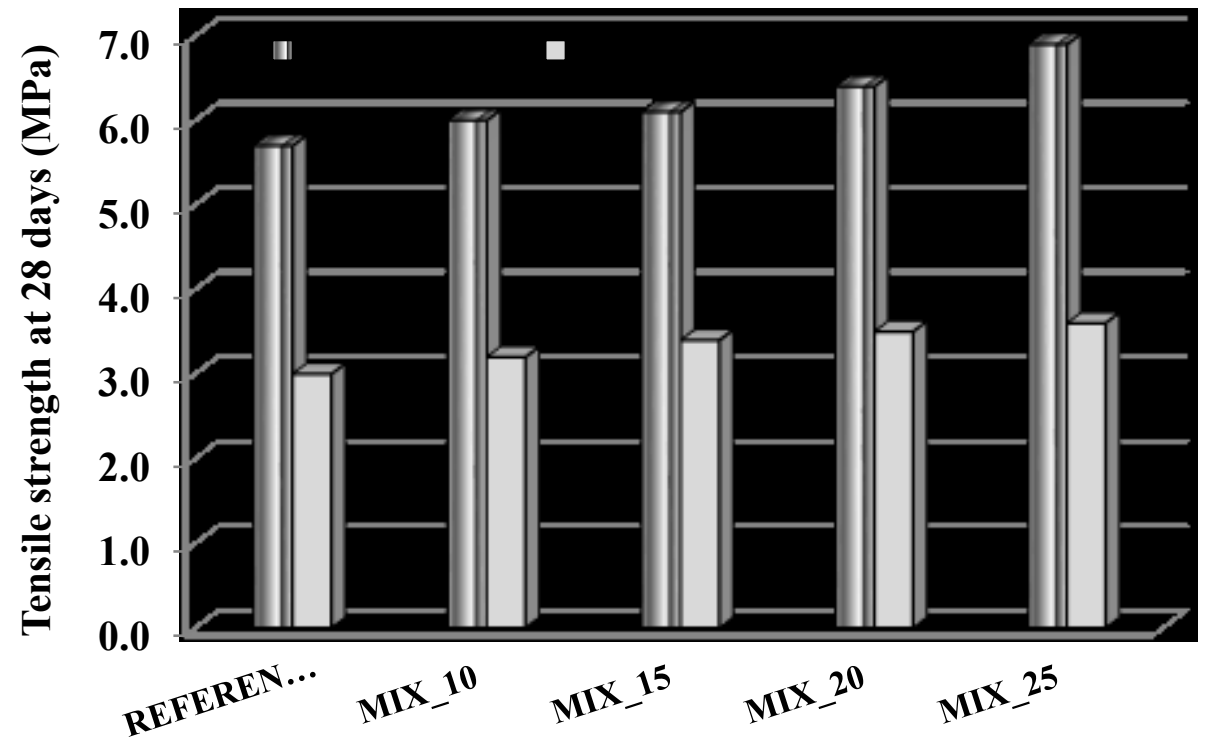

Figure 3. Flexural and splitting tensile strength of concrete mixes

Higher levels of waste aggregates replacement enhances dry shrinkage (Figure 4). To be specific, a $25 \%$ natural aggregates substitution leads to about $30 \%$ worsening in dry shrinkage. This effect can probably be ascribed to the water absorption and, consequently, the dry shrinkage can be reduced by a preventive soaking of aggregates with water before mixing. Due to the considerable shrinkage enhancement, the waste aggregates replacement must be limited to avoid severe cracking of concrete structures. 


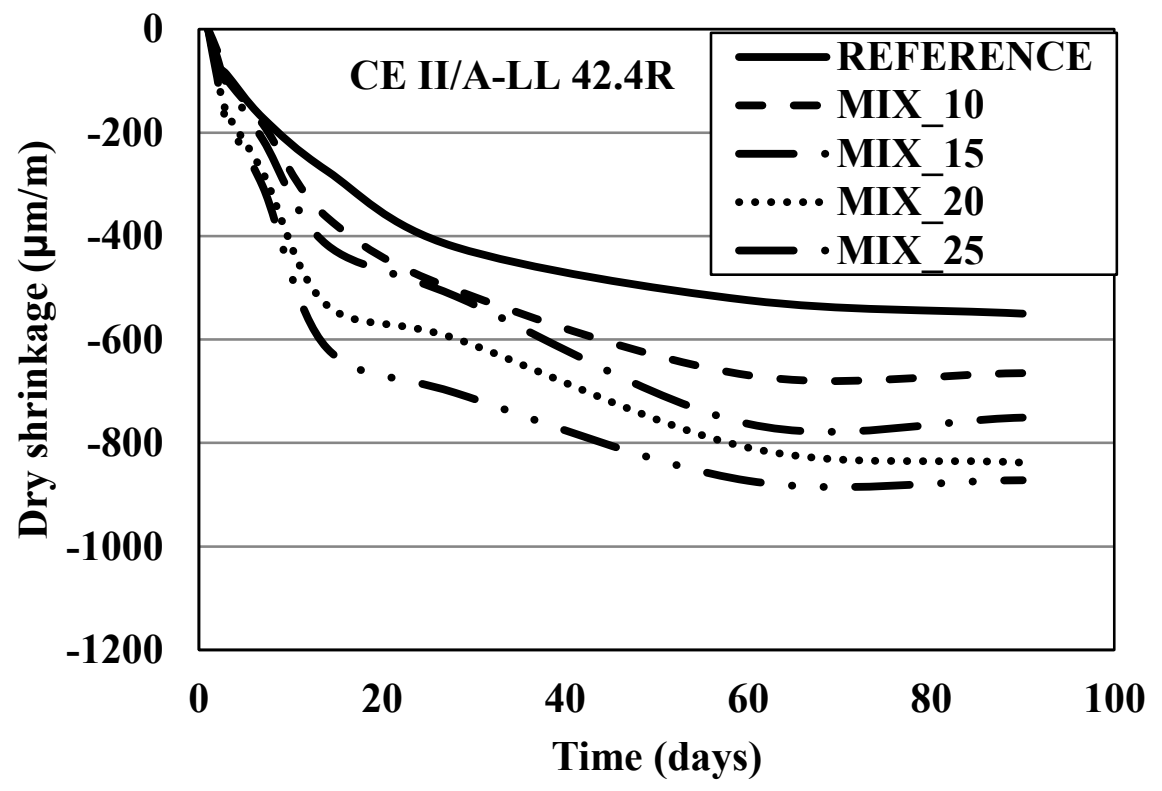

Figure 4. Drying shrinkage of concrete mixes

The Young Modulus of the hardened concrete was measured on cylindrical specimens at the age of 28 days (UNI-EN 6556). The higher the EAF granulated slag replacement was, the higher the Young Modulus (Figure 5). However, the increase of the Young Modulus is lower than that expected as a consequence of the higher density of mixes manufactured by adding a higher amount of EAF slag. A high value of the Young Modulus improves structural stiffness and reduces beam deflection. On the other hand, it enhances internal stress induced by restrained shrinkage. In conclusion, EAF granulated slag addition determines the need of an increase of mixing water (or superplasticizer dosage) and leads to an increase in slump loss of fresh concrete. Replacement of natural aggregates with EAF granulated slag improves the compressive strength, flexural and splitting tensile strengths of hardened concrete.

Moreover, the use of waste aggregates leads to an increase of the density, the elastic modulus in compression and the dry shrinkage of cementitious mixes. All the effects are summarized in Figure 6. A waste aggregates substitution above $15 \%$ promotes a slump loss at 60 minutes, $30 \%$ higher than that of the plain concrete and leads to a shrinkage worsening close to $50 \%$ if compared to the reference mix. On the basis of the experimental results, a maximum natural 
aggregates replacement of up to $15 \%$ is suggested to limit superplasticizer dosage, workability loss and shrinkage.

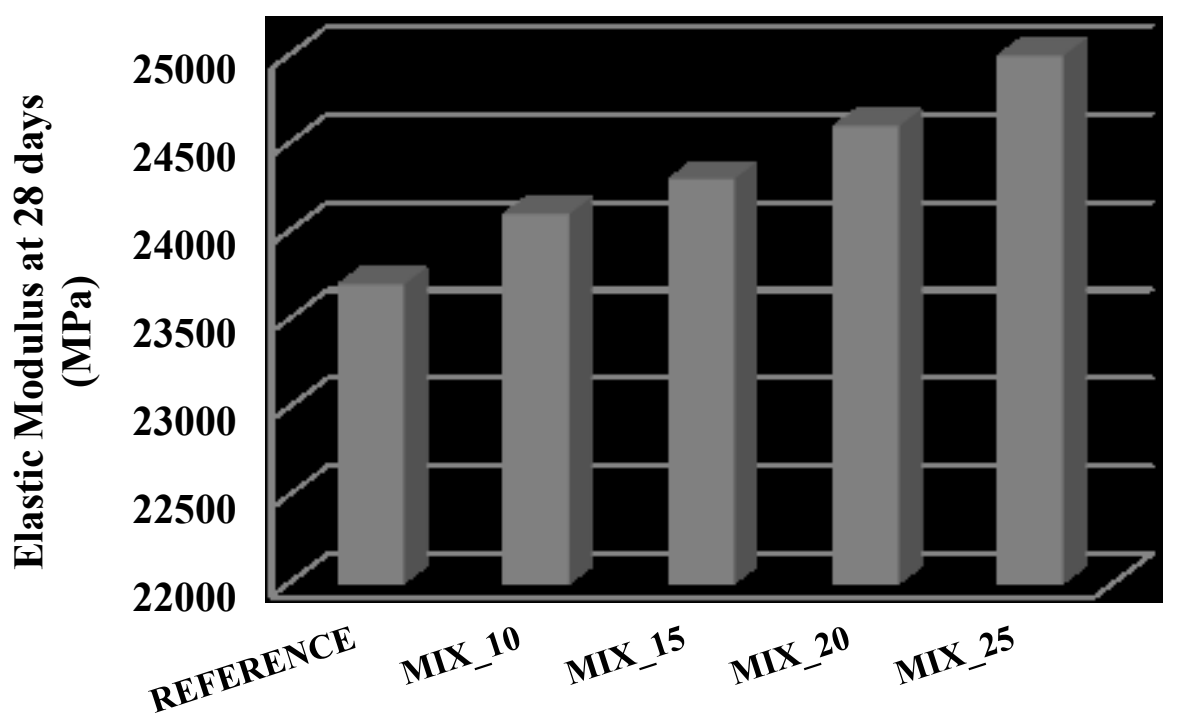

Figure 5. Elastic modulus of concrete mixes at 28 days

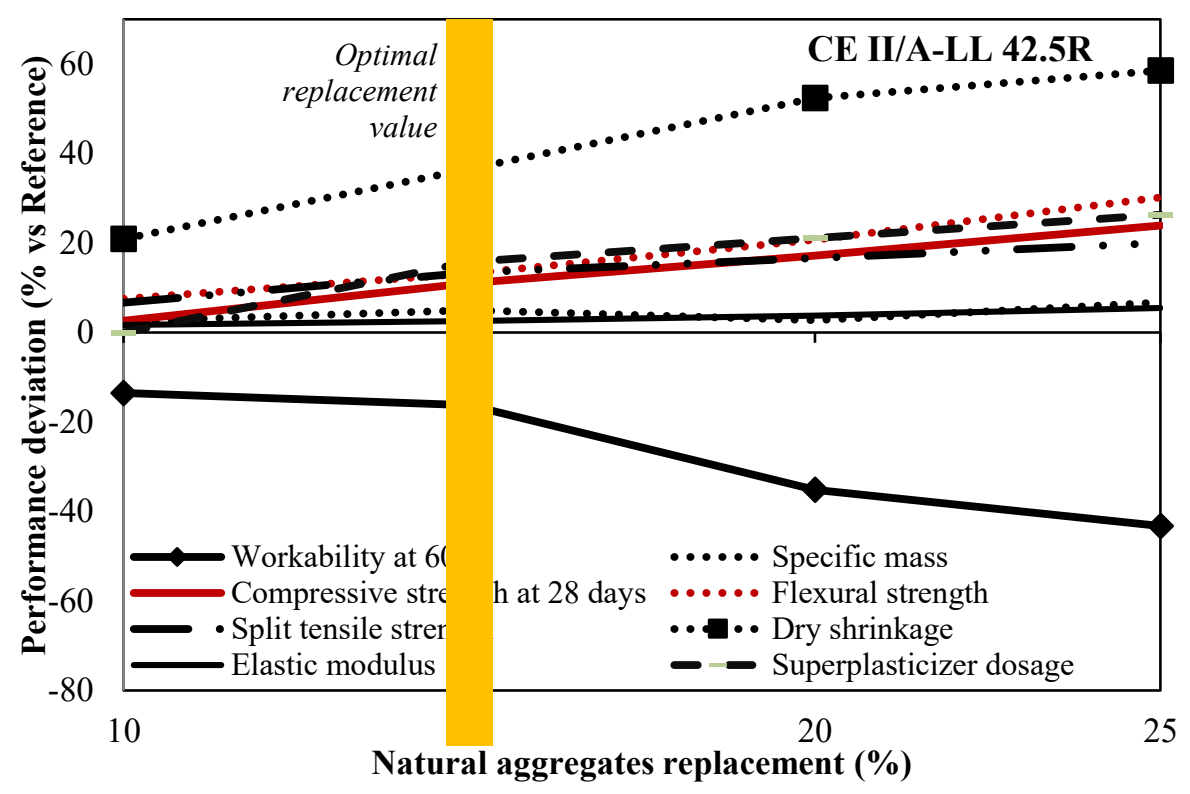

Figure 6. Performance deviation (\%) of concretes manufactured with waste aggregates compared to reference concrete 


\section{Conclusions}

Experimental results indicated that the maximum percentage of natural aggregate replaced with EAF granulated slag should be about $15 \%$ in order to limit the superplasticizer dosage to attain the same workability class (S4) of the reference mix at the end of the mixing procedure. The higher the percentage of granulated slag was, the higher the density, the elastic modulus in compression and the compressive strength of concrete. On the other hand, dry shrinkage of the concrete increases by adding a greater amount of EAF granulated slag. The use of EAF granulated slag for concrete production is limited by the higher density (higher dead loads and seismic vulnerability of the structures) and the higher sensitivity to cracks (higher elastic modulus and dry shrinkage) with respect to concrete manufactured using natural aggregates only. Despite the low optimal substitution percentage, limited to $15 \%$, it must be noted that nowadays, slag aggregates are commonly used to produce low-cost bituminous mixes for roads. Consequently, the possibility to use slag aggregates as a partial replacement in concrete should make the recycling procedure more attractive for steel manufacturers.

\section{References}

1. L. Coppola, T. Cerulli, D. Salvioni, Sustainable Development and Durability of SelfCompacting Concretes, Proc. 11th International Conference on Fracture 2005, ICF11, 3, 2226-2241.

2. G. A. Blengini, E. Garbarino, S. Šolar, D. J. Shields, T. Hámor, R. Vinai, Z. Agioutantis, Life Cycle Assessment guidelines for the sustainable production and recycling of aggregates: the Sustainable Aggregates Resource Management project (SARMa), J. Cleaner Production, 27, (2012) 177-181. http://dx.doi.org/10.1016/j.jclepro.2012.01.020

3. L. Coppola, S. Lorenzi, S.Pellegrini, Rheological and mechanical performances of concrete manufactured by using washing water of concrete mixing transport trucks, Durability and Sustainability of Concrete Structures - Workshop Proceedings, American Concrete Institute, ACI Special Publication, SP 305, (2015) 32.1- 32.12.

4. P. Kara, G. Moriconi, Design of high performance concrete with environmental benefits, Durability and Sustainability of Concrete Structures - Workshop Proceedings, American Concrete Institute, ACI Special Publication, SP 305, (2015) 39.1- 39.10. 
5. V. S. Ramachandran, Waste and By-products as Concrete Aggregates, Canadian Building Digest, CBD-215, National Research Council, Ottawa, Canada, 1981. http://www.irc.nrccnrc.gc.ca

6. M. Gimenez, C. Bouillon, F. Ferey, F. Sorrentino, Zero Waste. World Cement 09, 2005.

7. L. Coppola, S. Lorenzi, P.Marcassoli, G.Marchese, Concrete Production by Using Cast Iron Industry By-Products, Industria Italiana del Cemento, 836, (2007) 748-756.

8. H. Binici, T. Shah, O. Aksogan, H. Kaplan. Durability of concrete made with granite and marble as recycle aggregates, J Mater Process Tech, 208 (1-3), (2008) 299-308. http://dx.doi.org/10.1016/j.jmatprotec.2007.12.120

9. H. Binici, H. Zengin, G. Zengin, H. Kaplan, F. Yucegok. Resistance to sodium sulfate attack of plain and blended cement containing corncob ash and ground granulated blast furnace slag, Sci Res Essays, 4, (2009) 98-106.

10. H. Binici, M. Y. Durgun, T. Rizaoğlu, M. Koluçolak. Investigation of durability properties of concrete pipes incorporating blast furnace slag and ground basaltic pumice as fine aggregates, Scientia Iranica, Transactions A: Civil Engineering, 19(3), (2012) 366-372. http://dx.doi.org/10.1016/j.scient.2012.04.007

11. H. Binici, O. Aksogan, A. H. Sevinc, A. Kuçukonder. Mechanical and radioactivity shielding performances of mortars made with colemanite,barite, ground basaltic pumice and ground blast furnace slag, Constr Build Mater, $50 \quad$ (2014) 177-183. http://dx.doi.org/10.1016/j.conbuildmat.2013.09.033

12. P. Milella, Il ciclo industriale dell'acciaio da forno elettrico in Italia, Rapporti 38/2006 APAT, 2006.

13. EUROSLAG, http://www.euroslag.com

14. R. Sersale, V. Amicarelli, G.Frigione, P. Ubbriaco, Characterization and potential uses of steel slag, Silicates Industriels, 1986/11-12.

15. A. Monshi, M. K. Asgarani, Producing Portland cement from iron and steel slags and limestone, Cement Concrete Res, 29(9), (1999) 1373-1377. http://dx.doi.org/10.1016/S0008-8846(99)00028-9

16. C. Shi, J. Qian, High performance cementing materials from industrial slag - a review, Resour Conserv Recycl. 29(2), (2000) 195-207. http://dx.doi.org/10.1016/S09213449(99)00060-9

17. B. Das, S. Prakash, P. S. R. Reddy, V. N. Misra, An overview of utilization of slag and sludge from steel industries, Resour Conserv Recycl, 50(1), (2007) 40-57. http://dx.doi.org/10.1016/j.resconrec.2006.05.008. 
18. P. Y. Mahieux, J. E. Aubert, G. Escadeillas, Utilization of weathered basic oxygen furnace slag in the production of hydraulic road binders, Constr Build Mater, 23(2), (2009) 742747. http://dx.doi.org/10.1016/j.conbuildmat.2008.02.015

19. E. E. Hekal, S. A. Abo-El-Enein, S. A. El-Korashy, G. M. Megahed, T. M. El-Sayed, Hydration characteristics of Portland cement - Electric arc furnace slag blends, HBRC Journal. 9(2), (2013) 118-124. http://dx.doi.org/10.1016/j.hbrcj.2013.05.006.

20. Binici $\mathrm{H}$, Aksogan $\mathrm{O}$, Kaplan $\mathrm{H}, \mathrm{A}$ study on cement mortars incorporating plain Portland cement (PPC), ground granulated blast-furnace slag (GGBFS) and basaltic pumice, Indian J Eng Mater S, 12, (2005) 214-220.

21. H. Binici, O. Aksogan. Sulfate resistance of plain and blended cement, Cement Concrete Comp, 28(1), (2006) 39-46. http://dx.doi.org/10.1016/j.cemconcomp.2005.08.002

22. H. Binici, H. Temiz, M. M. Kose. The effect of fineness on the properties of the blended cements incorporating ground granulated blast furnace slag and ground basaltic pumice, Constr Build Mater, 21(5), (2007) 1122-1128. http://dx.doi.org/ 10.1016/j.conbuildmat.2005.11.005

23. Maslehuddin, A. M. Sharif, M. Shameem, M. Ibrahim, M. S. Barry, Comparison of properties of steel slag and crushed limestone aggregate concretes, Constr Build Mater, 17(2), (2003) 105-112. http://dx.doi.org/10.1016/S0950-0618(02)00095-8

24. A.- E. Samir, A. S. El-Dieb, M. S. Bedir, Performance of concrete mixtures made with electric arc furnace (EAF) steel slag aggregate produced in the Arabian Gulf region, Constr Build Mater, 34, 249-256. http://dx.doi.org/10.1016/j.conbuildmat.2012.02.012.

25. S. Monosi, M. L. Ruello, D. Sani, Electric arc furnace slag as natural aggregate replacement in concrete production, Cement Concrete Comp, 66, (2016) 66-72. http://dx.doi.org/10.1016/j.cemconcomp.2015.10.004

26. R. Z. Al-Zaid, F.H. Al-Sugair, A. I. Al-Negheimish, Investigation of potential uses of electric-arc furnace dust (EAFD) in concrete, Cement Concrete Res, 27(2), (1997) 267278. http://dx.doi.org/10.1016/S0008-8846(96)00204-9

27. F. Anastasiou, I. Papayianni, Criteria for the use of steel slag aggregates in concrete. Measuring, monitoring and modeling concrete properties, Springer Netherlands, (2006) 419-426. http://dx.doi.org/10.1007/978-1-4020-5104-3_51

28. M. Chen, M. Zhou, S. Wu, Optimization of blended mortars using steel slag sand, J Wuhan University of Technology, 22(4), (2007) 741-744.

29. Y. Lun, M. Zhou, X. Cai, F.Xu, Methods for improving volume stability of steel slag as fine aggregates, J Wuhan University of Technology, 23(5), (2008) 737-742. 
30. N. Faraone, G. Tonello, E. Furlani, S. Maschio, Steelmaking slag as aggregates for mortars: effects of particle dimension on compression strength, Chemosphere, $77(8)$, (2009) 1152-1156. http://dx.doi.org/10.1016/j.chemosphere.2009.08.002

31. C. Pellegrino, V. Gaddo, Mechanical and durability characteristics of concrete containing EAF slag as aggregate, Cement Concrete Comp, 31(9), (2009) 663-671. http://dx.doi.org/10.1016/j.cemconcomp.2009.05.006

32. L. Coppola, A. Buoso, S. Lorenzi, Compatibility issues of NSF-PCE superplasticizers with several lots of different cement types (long-term results), Kuei Suan Jen Hsueh Pao / Journal of the Chinese Ceramic Society. 38(9), (2010) 1631-1637. 